\title{
Article
}

Doi 10.5943/sif/ 3/1/3

Copyright $@$ Institute of Animal Science, Chinese Academy of Agricultural Sciences

\section{Fungal species consortia on Nypa fruticans at Brunei}

\author{
Sarma $V^{1,2^{*}}$ and Hyde $\mathbf{K D}^{3}$ \\ ${ }^{1}$ Centre for Research in Fungal Diversity, Department of Ecology and Biodiversity, The University of Hong Kong, \\ Pokfulam Road, Hong Kong. \\ ${ }^{2}$ Department of Biotechnology, School of Life Sceinces, Pondicherry University, Kalapet, Pondicherry - 605014, \\ India. \\ ${ }^{3}$ School of Science, Mae Fah Luang University, Chiang Rai, Thailand.
}

Sarma VV, Hyde KD 2018 - Fungal species consortia on Nypa fruticans at Brunei. Studies in Fungi 3(1), 19-26, Doi 10.5943/sif/3/1/3

\begin{abstract}
Studies on fungal species consortia of manglicolous fungi are very few. Observations of fungal species consortia may provide an idea on the fungal community structures and help in understanding ecosystem dynamics. In this paper, the fungal species consortia recorded on Nypa fruticans at Brunei is presented. Astrosphaeriella striatispora, Linocarpon appendiculatum, $L$. bipolaris, Neolinocarpon globosicarpa, Oxydothis nypae and Trichocladium nypae, were the frequently recorded fungi in this study. Three distinct fungal assemblages were found. One of these assemblages was typified by Astrosphaeriella striatispora, Linocarpon nypae and Oxydothis nypae in which the fungi occurred both in association with others as well as singly indicating a commensalistic occurrence. The second assemblage, was characterized by Linocarpon appendiculatum and Linocarpon bipolaris, the fungi occurred almost only in association with others, indicating a mutualistic behavior. The third assemblage was characterized by Anthostomella eructans, Anthostomella sp. and Trichocladium sp. which always occurred singly, indicating a possible antagonistic life style but the percentage occurrence of the last group was far low to attribute any antagonistic potential of these fungi in preventing other fungi from colonization.
\end{abstract}

Key words - co-occurrence - ecology - interactions - mangroves - marine fungi

\section{Introduction}

The information on fungal community ecology is more often acquired from macromycetes, which have different types of interactions as wood decay fungi (Boddy 2000). In general, the interactions between wood decay fungi are mostly antagonistic that may also lead to succession. This succession may often result due to resource capture through a combat among different fungi (Boddy 2000). In the process some fungi seem to facilitate establishing of certain specialized species (Niemelä et al. 1995). Whether it is positive or negation relationship, the co-occurrence of some species is merely due to their similar habitat requirements (Ovaskainen et al. 2010). The major changes in fungal species composition and richness occur with the progression in wood decay (Renvall 1995, Høiland \& Bendiksen 1997, Heilmann-Clausen 2001, Fukasawa et al. 2009, Rajala et al. 2011, Pouska et al. 2013). In the case of spruce logs, it has been found that the size influences the species composition (Høiland \& Bendiksen 1997, Pouska et al. 2011, Rajala et al. 2011) and richness (Høiland \& Bendiksen 1997). In most fungi the late stages of wood 
decomposition seem to be independent, appearing and disappearing without evident correlations to other decayers (Niemelä et al. 1995). It has been found that differences in the inoculation of wood by fungi influence subsequent species turnover (Fukami et al. 2010). Renvall (1995) has reported that Fomitopsis pinicola (Swartz: Fr.) P. Karst. is one of the important primary decayers of spruce wood and several other species regularly co-occur together with it. On the other hand, Ovaskainen et al. (2010) did not find either positive or negative correlations with several species.

Studies based on reproductive structures of fungi found on natural samples have limited potential to reveal causal relationships in the occurrence of fungal species (Pouska et al. 2013). A better proof of the effect of any species on others would be through a manipulative experiment in which $\operatorname{logs}$ would be artificially inoculated by a fungus. However, it would be extremely difficult to carry out experiments in the field, with such artificial inoculations, especially to control or reveal species assemblages (Pouska et al. 2013). Therefore, relying on species co-occurrence patterns with accounting for possible effects of other factors still seems to be a good way (Ovaskainen et al. 2010). In the case of wood decaying macromycetes on spruce it was found that dominant fungi, especially primary decayers, probably influence other fungi growing together with them. Fomitopsis pinicola is one of the important primary decayers, and it was shown that several other species regularly co-occur together with it thus influencing the species composition e.g. Antrodiella citronella and Camarops tubulina co-occuring with F. pinicola (Pouska et al. 2013). It has been reported by Weber (2006) that spring sap-flow quickly becomes colonized by yeasts and filamentous fungi, of which several species occur regularly in consortia from different trees or regions. They also reported that the competition within and between sap-flow yeast species may be due to nutritional effects or the action of killer toxins (mycocins).

Studies on community ecology of fungi on natural samples with reference to co-occurrence are few. The terms such as co-occurrence, unit communities, fungal assemblages, guilds, fungal species consortia seem to be synonymous (Cooke \& Rayner 1984). In a recent paper, it has been reported that three different fungal assemblages of manglicolous fungi were seen, namely, commensalistic, mutualistic and antagonistic life styles (Sarma \& Raghukumar 2013). The biodiversity and ecological observations such as horizontal, vertical distribution and frequency of occurrence of filamentous fungi of mangrove palm Nypa fruticans along the Tutong River, Brunei were reported earlier (Hyde \& Sarma 2006). In this paper the fungal species consortia occurring on Nypa fruticans along the Tutong River, Brunei are reported.

\section{Materials and Methods}

Dead and decomposing frond and leaf samples of Nypa fruticans, were collected from Tutong River, Brunei (lat. $04^{\circ} 47^{\prime} \mathrm{N}$; long. $114^{\circ} 41^{\prime} \mathrm{E}$ ) during July 1999. The data on the physico-chemical conditions of the sites and other details of the four sites from where the samples have been collected were published in Fryar et al. (2004), Hyde \& Sarma (2006). In total 120 samples were collected and all had a similar size of $20 \mathrm{~cm}$. The 120 samples (60 fronds and 60 leaves) were randomly collected and examined for saprobic filamentous fungi following incubation. Samples were examined under a stereo-zoom microscope after incubation in moist chambers starting from the first week onwards to 2 months by following the direct examination method (Kohlmeyer \& Kohlmeyer 1979, Hyde et al. 2000). Fungi were identified morphologically based on the fruiting structures of different fungi on each of the natural sample and recorded separately. The percentage occurrence of each fungus was calculated as the number of occurrences of a particular fungus divided by total number of fungal occurrences of all fungi multiplied by 100 . Based on the percentage occurrence then frequency groupings are made such as above $10 \%$ as "very frequent" (very frequently occurring fungi), $5-10 \%$ as "frequent", 1-5\% "occasional" and below $1 \%$ as "rare".

\section{Results}

Totally 46 fungal species were recorded on Nypa fruticans samples including 33 ascomycetes and 13 anamorphic taxa. Linocarpon bipolaris (13\%) followed by L. appendiculatum (12.5\%) and Oxydothis nypae (10.4\%) were "very frequent" in their occurrence, while Astrosphaeriella 
striatispora (6.2\%), Trichocladium nypae (6.2\%), Linocarpon nypae (6.2\%) were "frequent". Twenty-three fungi were recorded only once and were considered as "rare" in their occurrence on this host. In total 192 fungal occurrences were recorded from 120 samples. Such percentage calculations and in turn converting them into different 'frequency groupings' would also help us to verify whether a very frequent fungus also has high frequency of 'co-occurrence' with other fungi or not (Table 1).

Table 1 Pattern of fungal species consortia (co-occurrence) on Nypa fruticans.

\begin{tabular}{|c|c|c|c|c|c|c|}
\hline S.No. & Name of the species & $\begin{array}{l}\text { No. of } \\
\text { samples in } \\
\text { which a } \\
\text { fungus had } \\
\text { co-occurrence }\end{array}$ & $\begin{array}{l}\text { No. of } \\
\text { samples in } \\
\text { which a } \\
\text { fungus had no } \\
\text { co-occurrence }\end{array}$ & $\begin{array}{l}\text { Total } \\
\text { fungal } \\
\text { occur- } \\
\text { rences }\end{array}$ & $\begin{array}{l}\% \text { of } \\
\text { occur- } \\
\text { rence }\end{array}$ & $\begin{array}{l}\text { Number of other } \\
\text { fungal species } \\
\text { with which a } \\
\text { particular fungus } \\
\text { had co-occurrence }\end{array}$ \\
\hline 1. & $\begin{array}{l}\text { Aniptodera } \\
\text { chesapeakensis }\end{array}$ & 2 & - & 2 & $1.0 \%$ & 7 \\
\hline 2. & Aniptodera intermedia & 1 & - & 1 & $0.5 \%$ & 5 \\
\hline 3. & Aniptodera mangrovei & 3 & - & 3 & $1.6 \%$ & 4 \\
\hline 4. & Aniptodera nypae & 3 & 1 & 4 & $2.1 \%$ & 3 \\
\hline 5. & Annulatascus velatospora & 1 & - & 1 & $0.5 \%$ & 1 \\
\hline 6. & $\begin{array}{l}\text { Annulatascus } \mathrm{cf} \\
\text { velatospora } 1\end{array}$ & 5 & 1 & 6 & $3.1 \%$ & 11 \\
\hline 7. & $\begin{array}{l}\text { Annulatascus } \mathrm{cf} . \\
\text { velatospora } 2\end{array}$ & 2 & - & 2 & $1.0 \%$ & 4 \\
\hline 8. & Annulatascus sp.-like & 1 & - & 1 & $0.5 \%$ & 1 \\
\hline 9. & Anthostomella eructans & - & 1 & 1 & $0.5 \%$ & - \\
\hline 10. & Anthostomella nypensis & 1 & - & 1 & $0.5 \%$ & 2 \\
\hline 11. & Anthostomella sp. & - & 1 & 1 & $0.5 \%$ & - \\
\hline 12. & Astrosphaeriella aquatica & 1 & - & 1 & $0.5 \%$ & 2 \\
\hline 13. & Astrosphaeriella nypae & 5 & 1 & 6 & $3.1 \%$ & 5 \\
\hline 14. & $\begin{array}{l}\text { Astrosphaeriella } \\
\text { striatispora }\end{array}$ & 8 & 4 & 12 & $6.2 \%$ & 12 \\
\hline 15. & Astrosphaeriella sp. & 1 & - & 1 & $0.5 \%$ & 2 \\
\hline 16. & Carinispora nypae & 2 & 1 & 3 & $1.6 \%$ & 3 \\
\hline 17. & Frondicola tunitricuspis & 3 & 2 & 5 & $2.6 \%$ & 5 \\
\hline 18. & Helicascus nypae & 2 & - & 2 & $1.0 \%$ & 8 \\
\hline 19. & Herpotrichea nypicola & 1 & - & 1 & $0.5 \%$ & 1 \\
\hline 20. & Lignincola laevis & 1 & - & 1 & $0.5 \%$ & 2 \\
\hline 21. & Linocarpon angustatum & 2 & 1 & 3 & $1.6 \%$ & 4 \\
\hline 22. & $\begin{array}{l}\text { Linocarpon } \\
\text { appendiculatum }\end{array}$ & 21 & 3 & 24 & $12.5 \%$ & 19 \\
\hline 23. & Linocarpon bipolaris & 21 & 4 & 25 & $13.3 \%$ & 22 \\
\hline 24. & Linocarpon livistonae & 2 & - & 2 & $1.0 \%$ & 2 \\
\hline 25. & Linocarpon longisporum & 2 & - & 2 & $1.0 \%$ & 4 \\
\hline 26. & Linocarpon nypae & 6 & 6 & 12 & $6.2 \%$ & 8 \\
\hline 27. & Lulworthia grandispora & 1 & 1 & 2 & $1.0 \%$ & 2 \\
\hline 28. & Lulworthia sp. & 1 & - & 1 & $0.5 \%$ & 2 \\
\hline 29. & Marinosphaera mangrovei & 1 & - & 1 & $0.5 \%$ & 2 \\
\hline 30. & $\begin{array}{l}\text { Neolinocarpon } \\
\text { globosicarpa }\end{array}$ & 7 & - & 7 & $3.6 \%$ & 6 \\
\hline 31. & Oxydothis nypae & 15 & 5 & 20 & $10.4 \%$ & 13 \\
\hline 32. & Cancellidium applanatum & 2 & - & 2 & $1.0 \%$ & 2 \\
\hline 33. & Dictyochaete sp. & 1 & - & 1 & $0.5 \%$ & 5 \\
\hline
\end{tabular}


Table 1 Continued.

\begin{tabular}{|c|c|c|c|c|c|c|}
\hline S.No. & Name of the species & $\begin{array}{l}\text { No. of } \\
\text { samples in } \\
\text { which a } \\
\text { fungus had } \\
\text { co-occurrence }\end{array}$ & $\begin{array}{l}\text { No. of } \\
\text { samples in } \\
\text { which a } \\
\text { fungus had no } \\
\text { co-occurrence }\end{array}$ & $\begin{array}{l}\text { Total } \\
\text { fungal } \\
\text { occur- } \\
\text { rences }\end{array}$ & $\begin{array}{l}\% \text { of } \\
\text { occur- } \\
\text { rence }\end{array}$ & $\begin{array}{l}\text { Number of other } \\
\text { fungal species } \\
\text { with which a } \\
\text { particular fungus } \\
\text { had co-occurrence }\end{array}$ \\
\hline 34. & Endophragmia sp. & 1 & - & 1 & $0.5 \%$ & 3 \\
\hline 35. & Helicorhoidon nypicola & 5 & - & 5 & $2.6 \%$ & 11 \\
\hline 36. & Papulospora sp. & 1 & - & 1 & $0.5 \%$ & 2 \\
\hline 37. & Phialogeniculata sp. & 1 & - & 1 & $0.5 \%$ & 1 \\
\hline 38. & Phoma sp. & 1 & - & 1 & $0.5 \%$ & 5 \\
\hline 39. & Phomatospora sp.-like & 1 & - & 1 & $0.5 \%$ & 5 \\
\hline 40. & Savoryella aquatica & 3 & - & 3 & $1.6 \%$ & 6 \\
\hline 41. & Savoryella lignicola & 1 & - & 1 & $0.5 \%$ & 3 \\
\hline 42. & Sporidesmium sp. & 3 & 3 & 6 & $3.1 \%$ & 3 \\
\hline 43. & Trichocladium nypae & 10 & 2 & 12 & $6.2 \%$ & 14 \\
\hline 44. & Trichocladium sp. & - & 1 & 1 & $0.5 \%$ & - \\
\hline 45. & $\begin{array}{l}\text { Unidentified hyphomycete } \\
\text { 1(VSB107) }\end{array}$ & 1 & - & 1 & $0.5 \%$ & 5 \\
\hline \multirow[t]{2}{*}{46.} & $\begin{array}{l}\text { Unidentified hyphomycete } \\
2 \text { (VSB105) }\end{array}$ & 1 & - & 1 & $0.5 \%$ & 2 \\
\hline & $\begin{array}{l}\text { Total number of fungi } \\
\text { recorded }\end{array}$ & 154 & 38 & 192 & & \\
\hline
\end{tabular}

Examination of 120 samples (60 fronds and 60 leaf samples) of Nypa fruticans revealed that 28 samples did not show any fungal fruiting structures even after prolonged incubation. The remaining 92 samples showed sporulating fungi. Of these 38 samples showed any single fungal species on each sample, 26 samples had any two fungal species on each sample, 16 samples had any three fungal species on each sample, 8 samples had any 4 fungal species on each sample, 2 samples had any 5 fungal species on each sample and 2 samples had any 6 fungal species on each sample (Table 2).

Some of the examples of the co-occurrence shown by the samples in the present study were as follows: (i) Aniptodera intermedia + Trichocladium nypae + Aniptodera chesapeakensis + Oxydothis nypae + Linocarpon appendiculatum + Annulatascus cf.velatispora $1=$ (totally 6 fungal species on a particular decaying sample) (ii) Dictyochaete sp. + Helicascus nypae + Phomatospora sp.-like + Phoma sp. + Linocarpon bipolaris + Unidentified hyphomycete (VSB1070) (6 fungal species on yet another sample), (iii) Frondicola tunitricuspis + Oxydothis nypae + Neolinocarpon globosicarpa + Annulatascus cf.velatispora 1 + Linocarpon appendiculatum (5 different fungal species on yet another different natural sample).

The percentage occurrence and comparison of each species occurring singly or in cooccurrence with other fungal species (in a consortium) is presented in table 1. Of a total of 46 fungi recorded in this study only three fungal species occurred singly and these are Anthostomella eructans, Anthostomella sp., and Trichocladium sp. The remaining fungi mostly observed to be having a co-occurrence with any one or more than one fungal species (Table 1). Thus 29 taxa had co-occurrence with other fungi in different combinations. For example, Linocarpon bipolaris had co-occurrence with 22 different fungal species but on different samples with either two fungi on each sample or up to 6 fungi on each sample as mentioned in the above paragraph. This was followed by $L$. appendiculatum which had co-occurrence with 19 other fungal species, Trichocladium nypae with 14, Astrosphaeriella striatispora 12, Annulatascus cf. velatospora 11, Helicorhoidon nypicola 11, Linocarpon nypae 8, Helicascus nypae 8, Aniptodera chesapeakensis 7 other fungi. While 32 fungi showed co-occurrence with less than 6 other fungal species 3 species did not have any co-occurrence (Tables 2,3 ). 
Table 2 Distribution of fungal occurrences on Nypa fruticans in Brunei.

\begin{tabular}{lccc}
\hline Number of samples & $\begin{array}{l}\text { Break-up of no. } \\
\text { of samples } \\
\text { examined }\end{array}$ & $\begin{array}{l}\text { No. of fungal } \\
\text { species on each } \\
\text { sample }\end{array}$ & Fungal occurrences \\
\hline $\begin{array}{l}\text { Number of samples without } \\
\text { sporulating fungi }\end{array}$ & 28 & 0 & - \\
$\begin{array}{l}\text { Number of samples supporting a } \\
\text { single sporulating fungus per sample }\end{array}$ & 38 & 1 & $38 \times 1=38$ \\
$\begin{array}{l}\text { Number of samples supporting two } \\
\text { sporulating fungi per sample }\end{array}$ & 26 & 2 & $26 \times 2=52$ \\
$\begin{array}{l}\text { Number of samples supporting three } \\
\text { sporulating fungi per sample }\end{array}$ & 17 & 3 & $16 \times 3=48$ \\
$\begin{array}{l}\text { Number of samples supporting four } \\
\text { sporulating fungi per sample }\end{array}$ & 8 & 4 & $8 \times 4=32$ \\
$\begin{array}{l}\text { Number of samples supporting five } \\
\text { sporulating fungi per sample }\end{array}$ & 2 & 5 & $2 \times 5=10$ \\
$\begin{array}{l}\text { Number of samples supporting six } \\
\text { sporulating fungi per sample }\end{array}$ & 2 & 6 & $2 \times 6=12$ \\
Total & 120 & & $=192$ \\
\hline
\end{tabular}

Table 3 No. of other fungal species with which a particular fungus occurs.

\begin{tabular}{lc}
\hline Name of the species & $\begin{array}{l}\text { No. of other fungal species with which the particular fungus } \\
\text { had co-occurrence }\end{array}$ \\
\hline Linocarpon bipolaris & 22 \\
Linocarpon appendiculatum & 19 \\
Trichocladium nypae & 14 \\
Astrosphaeriella striatispora & 12 \\
Annulatascus cf. velatospora & 11 \\
Helicorhoidon nypicola & 11 \\
Linocarpon nypae & 8 \\
Helicascus nypae & 8 \\
Aniptodera chesapeakensis & 7 \\
Other fungi & Of the remaining 35 fungi out of total 46 fungi recorded, 3 had no \\
& co-occurrence while 32 had co-occurrence with 6 or less than 6 \\
& other fungal species \\
\hline
\end{tabular}

Table 4 Comparison of 'percentage of co-occurrence or occurring singly' of fungi on Nypa fruticans.

\begin{tabular}{lcc}
\hline Name of species & $\begin{array}{c}\text { \% co-occurrence with other } \\
\text { fungi }\end{array}$ & \% occurrence singly \\
\hline Linocarpon appendiculatum & 87.5 & 12.5 \\
Linocarpon bipolaris & 84 & 16 \\
Oxydothis nypae & 75 & 25 \\
Astrosphaeriella striatispora & 66.6 & 33.3 \\
Linocarpon nypae & 50 & 50 \\
\hline
\end{tabular}

\section{Discussion}

Co-occurrence patterns are used in ecology to explore interactions between organisms and environmental effects on co-existence within biological communities (Williams et al. 2014). Co- 
occurrence relationships are used to elucidate coexistence patterns of pairs of microbial taxa using checkerboard scores based on the presence or absence of organisms (Stone \& Roberts 1990) or larger datasets using correlation coefficients to represent either coexistence or competitive exclusion between two microbial taxa (Kittelmann et al. 2013). The fungal community inside a single log typically consists of several species, present as mycelia or as latent propagules, but only a small fraction of these fruit at a given point of time (Ovaskainen et al. 2010). Laboratory studies are indicative of competition for space and nutrients being the most common type of interaction between wood-decaying higher fungi (Boddy 2000, Heilmann-Clausen \& Boddy 2005), although many types of facultative and even mutualistic interactions have also been documented (Ovaskainen et al. 2010). Co-occurrence of fungi on natural samples may show a commensalistic (signifying a tolerance to other species) or a mutualistic association (Pouska et al. 2013, Sarma \& Raghukumar 2013). On the contrary, mutualism may imply that such species depended on each other in a mutualistic or a parasitic association. Decaying plant litter that contains lignocellulose is a complex substrate of lignin, cellulose and hemicellulose in addition to rapidly leaching labile organics (Raghukumar et al. 1994, Reddy 1995, Kausar et al. 2010). The lignocellulose substrate of different decaying plant materials may be degraded by a consortium of fungi in a commensalistic or mutualistic way (Sarma \& Raghukumar 2013).

In the present study, Oxydothis nypae (10.4\%), Astrosphaeriella striatispora (6.2\%), Linocarpon nypae $(6.2 \%)$ which were frequently recorded species, occurred both in consortia (cooccurrence with other fungi) and as 'single fungal occurrences' (individually) in more or less equal proportions (Table 1). These species could be considered as commensals in that their association with other species is not necessarily dependent on others (Kausar et al. 2010, Pouska et al. 2013). A similar pattern was observed with manglicolous fungi colonizing Rhizophora mucronata in mangroves of Goa, west coast of India (Sarma \& Raghukumar 2013). The difference however on $R$. mucronata is that the fungus Aigialus grandis showed commensalistic occurrence.

Linocarpon bipolaris (13.3\%) followed by L. appendiculatum $(12.5 \%)$ were the very frequently recorded species with high percentage occurrence. These two species always had cooccurrence with other fungi i.e. occurred mostly in association with other fungal species $(87.5 \%$ and $84 \%$ of the occurrences, respectively) (Table 4) indicating a mutualistic association. This may also point out that these species are dependent upon other fungi for their colonization. It has been proved under controlled conditions that dominant fungi, especially primary decayers, influence other fungi growing together with them to form fungal species consortia e.g. Fomitopsis pinicola on spruce logs (Pouska et al. 2013). Hence it may be surmised that these two fungi are not only dominant colonizers but are also accommodative for other fungi and live in a mutualistic association with other fungi. In a study on the endophytic fungal assemblages on maize it has been found that there were positive fungal interactions in the co-occurrence of fungi in the case of culture-dependent analyses but negative interactions in the case of culture-independent analyses (Pan \& May 2009). Only laboratory experiments will throw light whether the above two fungi viz., $L$. appendiculatum and $L$. bipolaris have enough enzymatic arsenal to colonize and establish the host substrate individually or are they dependent on other fungi, as a consortium, to break down the lignocellulosic complex. Also such studies should target their competition and antagonistic properties that exclude other fungi from colonization (Zare-Maivan \& Shearer 1988, Shearer 1995, Yuen et al. 1999, Fryar et al. 2001, 2005). In the case of $R$. mucronata the fungi such as Trichocladium achrasporum and Verruculina enalia were found to be the having a mutualistic behavior. The hosts Rhizophora spp. and Nypa fruticans have several host specific fungi colonizing them. The common fungi between the two host species are very few (Hyde et al. 2000). In the case of Avicennia officinalis it was Lignincola laevis which co-occurred with other fung in $72 \%$ of samples (Maria \& Sridhar 2017). Hence each host, when seen individually, has its own commensalistic, mutualistic and antagonistic fungal species.

Only three fungi, namely, Anthostomella eructans, Anthostomella sp. and Trichocladium sp. were found occurring singly on samples but their percentage occurrence was far low to attribute any antagonistic potential of these fungi in preventing other fungi from colonization. Once again it 
has to be proved in the in-vitro culture studies whether these fungi have any antagonistic potential or not. On the host $R$. mucronata, the fungus Rimora mangrovei was having antagonistic life style which could be ratified by its high percentage occurrence in occurring singly (Sarma \& Raghukumar 2013). This is unlike the three fungi, viz., Anthostomella eructans, Anthostomella sp. and Trichocladium sp. which were recorded with very low overall percentage occurrence and hence their occurring singly cannot be definitely attributable to them for an antagonistic mode of life.

The average number of fungi per sample found in this study was 1.6 even though 28 samples out of 120 samples examined did not show any fungal fruiting structures even after incubation for up to two months. It is interesting to note that the average number of fungi per sample was high in the submerged samples (2.5 per sample) than intertidal samples (1.57) or aerial samples $(0.75 \%)$ (Hyde \& Sarma 2006). The co-occurrence pattern also varied accordingly which was high in the submerged samples (data not shown here). This may indicate that the availability of water plays a vital role in fungal diversity and the formation of 'fungal species consortia' (co-occurrence) on different samples.

There are many factors that could influence the co-occurrence of fungi. Hosts, as an environment, can have significant effects on microbial community composition and diversity (Tejesvi et al. 2006, Pan \& May 2009). In addition to the chemical composition of the host substratum and availability of moisture, different types of fungal interactions may also shape the fungal communities. The present study provides the base line data on the co-occurrence patterns on the host Nypa fruticans and cultural studies in future on this line may throw more light on the specific fungal interactions such as mutualism, commensalism or antagonism.

\section{Acknowledgements}

The authors would like to thank Sally Fryar in the collection of the samples and Helen Leung, Hong Kong University for technical assistance.

\section{References}

Boddy L. 2000 - Interspecific combative interactions between wood-decaying basidiomycetes. FEMS Microbiology and Ecology 31, 185-194.

Cooke RC, Rayner ADM. 1984 - Ecology of saprotrophic fungi. Longman, London.

Fryar SC, Tsui KM, Hodgkiss IJ, Hyde KD. 2001 - The influence of competition between tropical fungi on wood colonization in streams. Microbial Ecology 41, 245-251.

Fryar SC, Booth W, Davies J, Hodgkiss IJ, Hyde KD. 2004 - Distribution of fungi on wood in the Tutong River, Brunei. Fungal Diversity 17, 17-38.

Fryar SC, Booth W, Davies J, Hodgkiss IJ, Hyde KD. 2005 - Evidence of in situ competition between fungi in freshwater. Fungal Diversity 18, 59-71.

Fukami T, Dickie IA, Wilkie JP, Paulus BC et al. 2010 -Assembly history dictates ecosystem functioning: evidence from wood decomposer communities. Ecology Letters 13, 675-684.

Fukasawa Y, Osono T, Takeda H. 2009 - Dynamics of physiochemical properties and occurrence of fungal fruit bodies during decomposition of coarse woody debris of Fagus crenata. Journal of Forest Research 14, 20-29.

Heilmann-Clausen J. 2001 - A gradient analysis of communities of macrofungi and slime moulds on decaying beech logs. Mycological Research 105, 575-596.

Heilmann-Clausen J, Boddy L. 2005 - Inhibition and stimulation effects in communities of wood decay fungi: exudates from colonized wood influence growth by other species. Microbial Ecology 49, 399-406.

Høiland K, Bendiksen E. 1997 - Biodiversity of wood-inhabiting fungi in a boreal coniferous forest in Sor-Tondelag Country, Central Norway. Nordic Journal Botany 16, 643-659.

Hyde KD, Sarma VV. 2006 - Biodiversity and ecological observations on filamentous fungi of Nypa fruticans along the Tutong River, Brunei. Indian Journal of Marine Sciences 35, 297 307 
Hyde KD, Sarma VV, Jones EBG. 2000. Morphology and Taxonomy of Higher Marine Fungi. In: Hyde KD, Pointing, SB (eds), Marine Mycology-A Practical Approach, Fungal Diversity Press, Hong Kong, pp. 172-204.

Kausar H, Sariah M, Mohd Saud H, Alam MZ, Ismail MR. 2010 - Development of compatible lignocellulolytic fungal consortium for rapid composting of rice straw. International Biodeterioration and Biodegradation. 64, 594-600.

Kittelmann S, Seedort H, Walters WA, Clemente JC et al. 2013 - Simultaneous amplicon sequencing to explore co-occurrence patterns of bacterial, archaeal and eukaryotic microorganisms in rumen microbial communities. PloS ONE. 8:e47879. doi:10.1371/journal.pone.0047879.

Kohlmeyer J, Kohlmeyer E. 1979 - Marine Mycology: The Higher Fungi, Academic Press, NY, USA.

Maria GL, Sridhar KR. 2017 - Pattern of fungal colonization and co-occurrence on Avicennia officinalis woody litter in a South-western mangrove of India. KAVAKA 48, 17-21.

Niemelä T, Renvall P, Penttilä R. 1995 - Interactions of fungi at late stages of wood decomposition. Annales Botanici Fennici 32, 141-152.

Ovaskainen O, Hottola J, Siitonen J. 2010 - Modeling species co-occurrence by multivariate logistic regression generates new hypotheses on fungal interactions. Ecology 91, 2514-2521.

Pan JJ, May G. 2009 - Fungal-Fungal Association affect the assembly of endophyte communities in Maize (Zea mays). Microbial Ecology 58, 668-678.

Pouska V, Leps J, Svoboda M, Lepsova A. 2011 - How do log characteristics influence the occurrence of wood fungi in a mountain spruce forest? Fungal Ecolology 4, 201-209.

Pouska V, Svoboda M, Leps J. 2013 - Co-occurrence patterns of wood-decaying fungi on Picea abies logs: does Fomitopsis pinicola influence the other species? Polish Journal of Ecology 61, 119-134.

Raghukumar C, Raghukumar S, Chinnaraj A, Chandramohan TM, D’Souza, Reddy CA 1994 Laccase and other lignocellulose modifying enzymes of marine fungi isolated from the coast of India. Botanica Marina 37, 515-523.

Rajala T, Peltoniemi M, Hantula J, Makipaa R, Pennanen T. 2011 - RNA reveals succession of active fungi during the decay of Norway spruce logs. Fungal Ecology 4, 437-448.

Reddy CA. 1995 - The potential for white-rot fungi in the treatment of pollutants. Current Opinion in Biotechnology 6, 320-328.

Renvall P. 1995 - Community structure and dynamics of wood rotting Basidiomycetes on decomposing conifer trunks in northern Finland. Karstenia 35, 1-51.

Sarma VV, Raghukumar S. 2013 - Manglicolous fungi from Chorao mangroves, Goa, West coast of India: Observations on fungal species consortia. Kavaka 41, 18-22.

Shearer CA. 1995 - Fungal Competition. Canadian Journal of Botany 73(S1), 1259-1264.

Stone L, Roberts A. 1990 - The checkerboard score and species distributions. Oecologia 85, 74-79.

Tejesvi MV, Mahesh B, Nalini MS, Prakash HS et al. 2006 - Fungal endophyte assemblages from ethnopharmaceutically important medicinal trees. Canadian Journal of Microbiology 52, 427435.

Weber RWS. 2006 - On the ecology of fungal consortia of spring sap-flows. Mycologist 20, 140143.

Williams RJ, Howe A, Hofmockel KS. 2014 - Demonstrating microbial co-occurrence patterns within and between ecosystems. Frontiers in Microbiology 5, 358.

Yuen TK, Hyde KD, Hodgkiss IJ. 1999 - Interspecific interactions among tropical and subtropical freshwater fungi. Microbial Ecology 37, 257-262.

Zare-Maivan H, Shearer CA. 1988 - Extracellular enzyme production and cell wall degradation by freshwater lignicolous fungi. Mycologia 80, 365-375. 